struction. Azotaemia may complicate both conditions due to functional lower urinary tract obstruction.

In this case azotaemia was short term, judged by the changes in serum creatinine concentration and $\mathrm{HCO}_{3}{ }^{-}$in the eight days before admission to hospital. Bladder catheterisation facilitated recovery of renal function by relieving functional obstruction and maintaining urine volume. No recurrence of hydronephrosis and hydroureter took place after the removal of the catheter, a feature that is unusual in obstructive uropathy from physical causes.

There was a mild degree of urinary retention, indicated by the presence of $100 \mathrm{ml}$ residual urine, and there was evidence of trabeculation of the bladder wall. Urine was initially infected but the infection cleared quickly after a short course of antibiotic.

Urinary retention in women has often been attributed to a psychogenic cause but abnormalities on intravenous urography were not observed in 16 patients who underwent full urological investigation. ${ }^{2}$ Constipation ${ }^{3}$ or anticholinergic drug administration ${ }^{4}$ may occasionally provoke urinary retention, but these factors were not relevant in this case.

1 Welt LG, Hollander $\mathrm{W} \mathrm{Jr}$, Blythe WB. The consequences of potassium depletion f Chronic Dis 1960;11:213-54

Blaivas JG, Labib KB. Acute urinary retention in women. Complete urodynamic evaluation. Br $\mathcal{F}$ Urol 1977;56:383-9.

Murray K, Massey A, Feneley RCL. Acute urinary retention-a urodynamic assessment. Br J Urol $1984 ; 56: 468-73$.

Danziger LH, Horn JR. Disopyramide-induced urinary retention. Arch Intern

Accepted 28 fanuary) 1985

Singleton Hospital, Sketty, Swansea SA2 8QA

R R GHOSE, FRCP, consultant physician

H R JIVAN, MRCP, medical registrar

Correspondence to: Dr R Ghose.

\section{Unusual presentations of acanthosis nigricans and insulin resistance in a brother and sister}

The association of acanthosis nigricans and insulin resistance is well recognised but rarely reported. ${ }^{1}$ There are two main subgroups within the syndrome. In both there is an abnormality of binding of insulin to its receptor. Patients designated type A have no detectable antibodies to insulin receptors, but type $B$ patients, who tend to be older, do have these antibodies. Type $A$ is frequently associated with the polycystic ovarian syndrome, while type B syndrome is associated with autoimmunity - raised IgG values, antinuclear antibodies, and sicca syndrome being common findings."

There has been no report of an association of familial acanthosis nigricans-insulin resistance syndrome ${ }^{3}$ with organ specific autoimmune diseases. We describe two siblings with acanthosis nigricans, insulin resistance, and multiple organ specific antibodies who presented with hypogonadotrophic hypogonadism and hyperprolactinaemia.

\section{Case reports}

Cuie 1 -In 1979 a 25 year old man presented with gross obesity (154 kg) and hypogonadism. He was noted to have pigmentation in the axillae and groins, later confirmed by skin biopsy to be acanthosis nigricans. Serum testosterone, follicle stimulating hormone, and luteinising hormone concentrations ( $3.8 \mathrm{nmol} 1(1 \cdot 1 \mathrm{ng} / \mathrm{ml})$ (normal 9.5-24.5 nmol l (2.7-7.1 ng ml)); $1.2 \mathrm{mU} / 1$ (normal $0.2-6.0 \mathrm{mU} / 1$ ); and $3.4 \mathrm{mU} / 1$ (normal $4.0-10.0 \mathrm{mU} / 1$ ), respectively) confirmed hypogonadotrophic hypogonadism. Thyroid function values and serum prolactin concentrations were normal. Cortisol and growth hormone responses to insulin induced hypoglycaemia were normal. Radiography of the skull showed an expanded pituitary fossa. CT scan suggested an intrasellar adenoma, but at operation the fossa was empty. Result of an oral glucose tolerance test was normal but insulin concentrations were grossly raised. During a euglycaemic clamp study the glucose disposal rate ( $M$ value) was $2.35 \mathrm{mg} \mathrm{kg} / \mathrm{min}$ at an insulin infusion rate of $40 \mathrm{mU} / \mathrm{m}^{2} \mathrm{~min}$, indicating pronounced insulin resistance. Tests for antiadrenal antibodies and complement fixing islet cell antibodies gave positive results. Pituitary autoantibodies were not detected.

Case 2-Before her brother's acanthosis nigricans had been recognised a 35 year old woman presented with a one year history of secondary amenorrhoea and persistent galactorrhoea after the birth of her second child. Serum prolactin concentration was raised, ranging from 780 to
$1800 \mathrm{mU} 1$ (normal $<360 \mathrm{mU} \mathrm{1}$ ). She was obese $(80 \mathrm{~kg}$ ), had axillary and vulval acanthosis nigricans, and showed normal glucose tolerance with severely raised insulin concentrations (fig). $M$ value was $1.75 \mathrm{mg} / \mathrm{kg} / \mathrm{min}$ during a euglycaemic clamp study ai an insulin infusion rate of $40 \mathrm{mU} / \mathrm{m}^{2}$ ? $\mathrm{min}$, indicating insulin resistance. She had consistently abnormal ratios of luteinising hormone to follicle stimulating hormone and a serum testosterone concentration of $4.0 \mathrm{nmol} / 1(1.2 \mathrm{ng} / \mathrm{ml}$ ) (normal $0.5-2.8 \mathrm{nmol} / 1 ; 0 \cdot 1-0.8 \mathrm{ng}$; $\mathrm{ml}$ ). An ultrasound scan of the pelvis showed multiple small cysts in the left ovary, supporting a diagnosis of polycystic ovarian syndrome. She had antibodies to thyroid and gastric parietal cells but no pituitary autoantibodies.

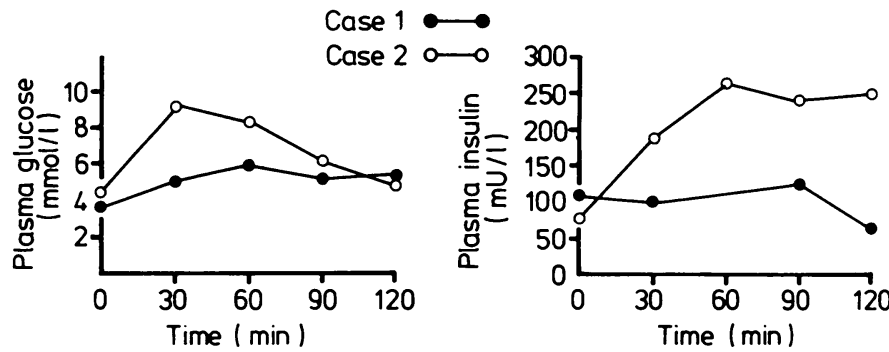

Plasma glucose and plasma insulin concentrations during $75 \mathrm{~g}$ oral glucose tolerance test in cases 1 and 2.

Conversion: SI to traditional units-Glucose: $1 \mathrm{mmol} / 1 \approx 18 \mathrm{mg} / 100 \mathrm{ml}$.

\section{Comment}

These two cases are unusual in several respects. The acanthosis nigricans-insulin resistance syndrome is rare in men; and few familial cases have been reported. The sister shared features of both type A (polycystic ovaries) and type B syndromes (multiple autoantibodies). We know of no other reports of hyperprolactinaemia or hypogonadotrophic hypogonadism as presenting features. The raised prolactin concentration seen in the sister may have been secondary to the polycystic ovarian syndrome. It is now recognised that there are abnormalities of the pulsatile release of luteinising hormone releasing hormone from the hypothalamus in the polycystic ovarian syndrome giving rise to altered ratios of luteinising hormone to follicle stimulating hormone, ${ }^{4}$ while hypogonadotrophic hypogonadism, as seen in the brother, is also usually secondary to a defect at hypothalamic level..$^{5}$ Our patients had multiple autoantibodies, but these did not include pituitary autoantibodies. An attractive unifying theory is that there may be an underlying autoimmune defect at hypothalamic level. These two cases also suggest that a wider variety of endocrine defects than currently recognised may be associated with acanthosis nigricans and insulin resistance.

We are indebted to Dr J A Weaver for his helpful comments, Mrs Marie Loughran for preparing the manuscript, and Dr G F Bottazzo and Dr M Haire for autoantibody studies.

1 Kahn CR, Flier JS, Bar RS, et al. The syndromes of insulin resistance and acanthosis nigricans. Insulin-receptor disorders in man. $N$ Engl $\mathcal{f}$ Med 1976; 294:739-45.

2 Flier JS, Kahn CR, Roth J. Receptors, antireceptor antibodies and mechanisms of insulin resistance. $N$ Engl f Med 1979;300:413-9.

3 Flier JS, Young JB, Landsberg L. Familial insulin resistance with acanthosis nigricans, acral hypertrophy and muscle cramps. $N$ Engl $\mathcal{F}$ Med 1980;303:

4 Zumoff B, Freeman R, Coupey S, et al. A chronobiologic abnormality in luteinizing hormone secretion in teenage girls with the polycystic ovary syndrome. $N$ Eng.

5 Hoffman AR, Crowley WF Jr. Induction of puberty in men by long-term pulsatile administration of low-dose gonadotropin-releasing hormone. $N$ Engl $\mathcal{F}$ Med 1982;307:1237-41.

(Accepted 8 fanuary 1985

Sir George E Clark Metabolic Unit, Royal Victoria Hospital, Belfast BT12 6BA, Northern Ireland

C M RITCHIE, MB, MRCP, registrar

$\mathrm{K}$ WALSHE, MB, research fellow

A L KENNEDY, MD, MRCP, consultant physician

W J ANDREWS, MD, MRCP, consultant physician

A B ATKINSON, MD, MRCP, consultant physician

Regional Endocrine Laboratory, Royal Victorian Hospital, Belfast BT12 6BA

B SHERIDAN, BA, MSC, biochemist

Royal Maternity Hospital and Queen's University of Belfast, Belfast BT12 6BB

A I TRAUB, MD, MRCOG, consultant lecturer

Correspondence to: Dr A B Atkinson. 